Original Research Article

\title{
Secondary Thrombocytosis as a poor prognostic indicator in ovarian carcinoma
}

\author{
Ramu S. ${ }^{1}$, Sandeepa S. $^{2}$, Sinha R. ${ }^{3}$, Murthy N. ${ }^{4}$ \\ ${ }^{1}$ Dr. Shwetha Ramu, Assistant Professor, Department of Pathology, Basaveshwara Medical College Hospital \& Research \\ Centre, Chitradurga, Karnataka, ${ }^{2}$ Dr. Supriya Sandeepa, Associate Professor, Department of Pathology, Akash Institute \\ of Medical Sciences and Research Centre, Bengaluru, Karnataka, ${ }^{3}$ Dr. Ruchi Sinha, Associate Professor, Department of \\ Pathology, Kasturaba Medical College, Mangaluru. Karnataka, ${ }^{4}$ Dr. Narayana Murthy, Professor and Head, Department \\ of Pathology, Basaveshwara Medical College Hospital \& Research Centre. Chitradurga, Karnataka, India.
}

Corresponding Author: Dr. Supriya Sandeepa, Associate Professor, Department of Pathology, Akash Institute of Medical Sciences and Research Centre, Bengaluru, Karnataka. E mail: shwethachandan@gmail.com

\begin{abstract}
Introduction: Secondary thrombocytosis has been identified in many solid tumors including ovarian carcinoma and has a poor prognostic value in many cases. Platelets and Platelet-related factors may contribute to metastasis, invasion and primary tumor growth. Objective: The objective of the present study is to determine the incidence of thrombocytosis in ovarian carcinoma and its importance as a poor prognosticator. Materials and methods: One sixty cases of epithelial ovarian tumors were studied prospectively between the period of October 2010 to June 2012 in the Department of Pathology, Kasturba Medical College Mangalore. Other causes of secondary thrombocytosis were excluded from the study. All the data for all the cases were obtained and were statistically analysed by Chi-square test and Fisher's exact test. Results: One sixty cases were studied in the present study. Mean age in the present study was 43.64 years and the mean age of patients with malignancy was 53.18 years. Majority of the cases were benign $(64.3 \%)$, followed by malignant $(31.3 \%)$ and borderline tumors $(4.4 \%)$. Mean platelet count in the study was $321 \times 10^{9} / \mathrm{L}$, and $80 \%$ of malignant cases had thrombocytosis as compared to $42.9 \%$ of borderline cases and $5.8 \%$ of benign cases, which is highly significant $(\mathrm{p}=0.0001)$. Predominant cases of ovarian carcinomas were in stage III $(80 \%)$ followed by stage IV $(17.5 \%)$ and stage II (2.5\%). Conclusion: Pre-operative secondary thrombocytosis is a frequent finding in ovarian carcinoma and is significantly associated with advanced FIGO stage. The presence of thrombocytosis acts as a poor prognosticator in epithelial ovarian carcinoma.
\end{abstract}

Key words: Secondary thrombocytosis, Surface epithelial ovarian tumors, Ovarian carcinoma, FIGO staging, Ascites, Poor prognosticator.

\section{Introduction}

Thrombocytosis refers to platelet count above the normal value (> $\left.400 \times 10^{9} / \mathrm{L}\right)$. Thrombocytosis is classified according to its origin intoprimary and secondary types $[1,2]$. Primary thrombocytosis refers to persistent elevation of platelet count due to clonal thrombopoiesis as found in chronic myeloproliferative and some myelodysplastic disorder [1,2]. Secondary thrombocytosis can be due to a variety of underlying conditions like acute inflammation, malignancy, postsplenectomy and others. Short-lived secondary thrombocytosis is observed in conditions such as trauma, acute bleeding or major surgical procedures $[2,3]$. Secondary thrombocytosis associated with

Manuscript received: $30^{\text {th }}$ November 2017

Reviewed: $8^{\text {th }}$ December 2017

Author Corrected: $15^{\text {th }}$ December 2017

Accepted for Publication: $20^{\text {th }}$ December 2017
Malignancy may persist for a longer time [2,4]. Malignancy is one of the most important causes of secondary thrombocytosis [2,5]. The association between thrombocytosis and malignancies has been well demonstrated since many years [6]. One third of all cancer patients demonstrate thrombocytosis at the time of diagnosis [7].

Thrombocytosis has been described as a clue to an underlying malignancy in some patients in whom the diagnosis has not yet been suspected or established [2]. It has been reported in variety of neoplastic diseases including Hodgkin lymphoma, sarcoma and several solid tumors such as lung, renal, gastric, breast, pancreatic, colonic and gynecological malignancies [4,7,8-20]. 


\section{Original Research Article}

In ovariancancer, thrombocytosisisa poor prognostic factor in locally advanced disease [5,21-24]. Chalas et al found thrombocytosis in $56 \%$ of the reviewed cases of epithelial ovarian malignancies.

Moreover, in the same study thrombocytosis was shown to have a predictive value of $83 \%$ and a specificity of $84 \%$ in differentiating malignant tumors from benign pelvic masses [25]. The etiology of neoplastic megakaryopoiesis remains unclear, it might be related to increased rate of platelet production [7, 8]. Increased platelet production are due to certain cytokines (IL-6, IL-1) and growth factors released by malignant cells.

Platelet aggregates with tumor cells prevents immune mediated tumor cell clearance. Thrombospondin-1 helps in adhesion of circulating tumor cells to endothelium, extra vasation of tumor cells and metastasis. Elevated platelet counts may also have a role in ovarian cancer growth and metastasis [9].

\section{Materials and Methods}

In the present study, 160 cases of epithelial ovarian tumors were studied.

Type of study: Prospective study.

Place of study: Department of Pathology, Kasturba Medical College, Mangalore.

Duration of study: 1 year 9 months (October 2010 to June 2012).

Sample collection: Cases were collected from Lady Goshen Hospital, Kasturba Medical College Hospital, Attavara and Ambedkar Circle.

The data were collected regularly during the study period from the case records at respective Medical Record Departments and laboratory reports at Kasturba Medical College Hospital, Ambedkar Circle.

All the data for all the cases were obtained.

\section{Inclusion criteria}

1) Clinical, serological \& radiological evidences of epithelial ovarian tumor.

2) Surgical and histopathological evidences of epithelial ovarian tumor.

\section{Exclusion criteria}

1) Acute inflammatory conditions.

2) History ofmyeloproliferative disorders.

3) Secondary overt malignancies.

4) Post-splenectomy patient.

5) Pre-operative chemotherapy

Sampling methods: The data collected in the present study were pre-operative platelet counts, stage (FIGO stagingTable 1), tumor histology and, the presence and degree of ascites among all the patients.

All patients underwent staging laparotomy. The gross specimens obtained after surgery were examined in detail. Tissue was fixed in $10 \%$ buffered formalin, and processed by paraffin embedding.

The blocks were serially cut, each of $3-5 \mu$ thickness and the sections counterstained with Haemotoxylin and Eosin (H\&E).

The routine $\mathrm{H}$ and $\mathrm{E}$ stained slides of all the cases were reviewed thoroughly and the histopathological findings were recorded.

As per the latest WHO classification, the epithelial ovarian tumors were divided histologicaly into benign, borderline and malignant. 


\section{Original Research Article}

Table-1: FIGO staging system for ovarian tumors- the International Federation of Gynaecological Oncologists.

\begin{tabular}{|c|c|}
\hline \multicolumn{2}{|c|}{ Stage1- Tumour is confined to the ovary / ovaries } \\
\hline $\mathbf{1 A}$ & $\begin{array}{l}\text { - Only one ovary is affected by the tumour, the ovary capsule is intact } \\
\text { - No tumour is detected on the surface of the ovary } \\
\text { - Malignant cells are not detected in ascites or peritoneal washings }\end{array}$ \\
\hline $1 B$ & $\begin{array}{l}\text { - Both ovaries are affected by the tumour, the ovary capsule is intact } \\
\text { - No tumour is detected on the surface of the ovaries } \\
\text { - Malignant cells are not detected in ascites or peritoneal washings }\end{array}$ \\
\hline $1 \mathrm{C}$ & $\begin{array}{l}\text { The tumour is limited to one or both ovaries, with any of the following: } \\
\text { - The ovary capsule is ruptured } \\
\text { - The tumour is detected on the ovary surface } \\
\text { - Positive malignant cells are detected in the ascites or peritoneal washings }\end{array}$ \\
\hline \multicolumn{2}{|c|}{ Stage 2 - Tumour involves one or both ovaries and has extended into the pelvis } \\
\hline $\mathbf{2 A}$ & $\begin{array}{l}\text { - The tumour has extended and/or implanted into the uterus and/or the fallopian tubes. } \\
\text { - Malignant cells are not detected in ascites or peritoneal washings }\end{array}$ \\
\hline 2B & $\begin{array}{l}\text { - The tumour has extended to another organ in the pelvis } \\
\text { - Malignant cells are not detected in ascites or peritoneal washings }\end{array}$ \\
\hline $2 \mathrm{C}$ & $\begin{array}{l}\text { - Tumours are as defined in } 2 \mathrm{~A} / \mathrm{B} \text {, and malignant cells are detected in the ascites or peritoneal } \\
\text { washings }\end{array}$ \\
\hline \multicolumn{2}{|c|}{$\begin{array}{l}\text { Stage 3- The tumour involves one or both ovaries with microscopically confirmed peritoneal metastasis } \\
\text { outside the pelvis and/or regional lymph node metastasis. } \\
\text { Includes liver capsule metastasis. }\end{array}$} \\
\hline 3A & - Microscopic peritoneal metastasis beyond the pelvis \\
\hline 3B & - Microscopic peritoneal metastasis beyond the pelvis $2 \mathrm{~cm}$ or less in greatest dimension \\
\hline $3 \mathrm{C}$ & $\begin{array}{l}\text { - Microscopic peritoneal metastasis beyond the pelvis more than } 2 \mathrm{~cm} \text { in greatest dimension } \\
\text { and/or regional lymph nodes metastasis }\end{array}$ \\
\hline \multicolumn{2}{|c|}{ Stage: 4 - Distant metastasis beyond the peritoneal cavity. And, liver parenchymal metastasis. } \\
\hline
\end{tabular}

Statistical methods: The incidence of thrombocytosis in the studied tumors were statistically analysed by Chi-square test. The patients with thrombocytosis were correlated with the FIGO stage and, presence and degree of ascites among malignant cases were statistically analysed by Chi-square test and Fisher's exact test. In the present study, a p value $<0.05$ was considered significant for the performed tests.

\section{Results}

In the present study, 160 cases of surface epithelial ovarian tumors (SEOT) were reviewed thoroughly. In an attempt to study the incidence of thrombocytosis among surface epithelial ovarian tumors, these tumors were classified into benign, borderline and malignant according to the recent WHO classification 2008 [26].

The mean age of all patients with SEOT was 43.64 years (median 42.00 years) as shown in Table 2. The mean age of patients for benign cases was 38.85 years. The mean age for borderline cases was 46 years, whereas the malignant had a mean age of 53.18 years. In the present study, out of 160 cases of surface epithelial ovarian tumors, majority of the cases were benign (64.3\%), followed by malignant (50\%) and borderline tumor cases $(4.4 \%)$ as depicted in Table 3 . 


\section{Original Research Article}

Table-2: Mean age among categories of surface epithelial ovarian tumors.

\begin{tabular}{|c|c|c|c|}
\hline & Benign & Borderline & Malignant \\
\hline Total number of cases & 103 & 07 & 30 \\
\hline Minimum age (years) & 17 & 30 & 80 \\
\hline Maximum age (years) & 75 & 66 & 53.18 \\
\hline Mean (years) & 38.85 & 46 & 11.24 \\
\hline SD & 12.61 & 12.50 & 35 \\
\hline
\end{tabular}

Table-3: Frequency of categories of surface epithelial ovarian tumors.

\begin{tabular}{|c|c|c|}
\hline SEOT & Number of cases & Percentage \\
\hline Benign & 103 & $64.3 \%$ \\
\hline Borderline & 07 & $4.4 \%$ \\
\hline Malignant & 50 & $31.3 \%$ \\
\hline
\end{tabular}

In the present study, serous ovarian tumors (70.6\%) were the most common histologic type, followed by mucinous $(27.5 \%)$ tumors. $49(30.6 \%)$ cases of surface epithelial ovarian tumors had thrombocytosis. The platelet count ranged from $172 \times 10^{9} / \mathrm{L}$ to $641 \times 10^{9} / \mathrm{L}$ and mean the value was $321 \times 10^{9} / \mathrm{L}$. In this study $80 \%$ of malignant cases had preoperative thrombocytosis, as compared to $42.9 \%$ of borderline cases and $5.8 \%$ of benign cases, which is highly significant ( $\mathrm{p}=0.0001)$ (Table 4$) .43(26.9 \%)$ cases had ascites. The presence and degree of ascites was more in malignant SEOTs, than in borderline and benign tumors, and this finding was statistically highly significant $(\mathrm{p}=0.001)$. Ascites was moderate to massive in $42 \%$ and $36 \%$ cases, respectively of malignant SEOTs. Minimal ascites was present in $14 \%$ cases of borderline SEOTs. None of the benign SEOTs had ascites (Fig 1).

Table-4: Distribution of pre-operative platelet count among surface epithelial ovarian tumors.

\begin{tabular}{|c|c|c|c|c|c|}
\hline \multicolumn{2}{|c|}{ Surface epithelial ovarian tumors } & \multirow{2}{*}{$\begin{array}{c}\begin{array}{c}\text { Number of } \\
\text { cases }\end{array} \\
66\end{array}$} & \multirow{2}{*}{$\begin{array}{c}\begin{array}{c}\text { Mean platelet } \\
\text { count }(\mathbf{X 1 0} / \mathbf{L})\end{array} \\
262\end{array}$} & \multirow{2}{*}{$\begin{array}{c}\begin{array}{c}\text { Lowest value } \\
\left(\mathbf{X 1 0} \mathbf{9}^{\mathbf{9}} / \mathbf{L}\right)\end{array} \\
172\end{array}$} & \multirow{2}{*}{$\begin{array}{c}\begin{array}{c}\text { Highest value } \\
\left(\mathbf{X 1 0} \mathbf{9}^{\mathbf{}} / \mathbf{L}\right)\end{array} \\
479\end{array}$} \\
\hline Benign & SCA & & & & \\
\hline & MCA & 37 & 263 & 192 & 484 \\
\hline \multirow[t]{2}{*}{ Borderline } & Serous borderline & 5 & 370 & 278 & 42 \\
\hline & $\begin{array}{l}\text { Mucinous } \\
\text { borderline }\end{array}$ & 2 & 401 & 397 & 405 \\
\hline \multirow[t]{3}{*}{ Malignant } & SCAC & 42 & 444 & 249 & 641 \\
\hline & MCAC & 5 & 373 & 226 & 464 \\
\hline & Others & 3 & 409 & 288 & 507 \\
\hline
\end{tabular}

SCA- Serous cystadenoma, SCAC- Serous cystadenocarcinoma, MCA- Mucinous cystadenoma, MCACMucinous cystadenocarcinoma

Table-5: Correlation of thrombocytosis with FIGO staging in malignant ovarian tumors(ovarian carcinoma)

\begin{tabular}{|c|c|c|c|c|c|}
\hline \multirow[t]{2}{*}{ Platelet count } & \multicolumn{4}{|c|}{ FIGO staging } & \multirow[t]{2}{*}{ Total } \\
\hline & I & II & III & IV & \\
\hline$<400 \times 10^{9} / \mathrm{L}$ & $\begin{array}{c}5 \\
(50 \%)\end{array}$ & $\begin{array}{c}1 \\
(10 \%)\end{array}$ & $\begin{array}{c}4 \\
(40 \%\end{array}$ & $\begin{array}{c}0 \\
(0 \%)\end{array}$ & $\begin{array}{c}10 \\
(100 \%)\end{array}$ \\
\hline$>400 \times 10^{9} / \mathrm{L}$ & $\begin{array}{c}0 \\
(0 \%)\end{array}$ & $\begin{array}{c}1 \\
(2.5 \%)\end{array}$ & $\begin{array}{c}32 \\
(80 \%)\end{array}$ & $\begin{array}{c}7 \\
(17.5 \%)\end{array}$ & $\begin{array}{c}40 \\
(100 \%)\end{array}$ \\
\hline Total & 5 & 2 & 36 & 7 & 50 \\
\hline
\end{tabular}


Original Research Article

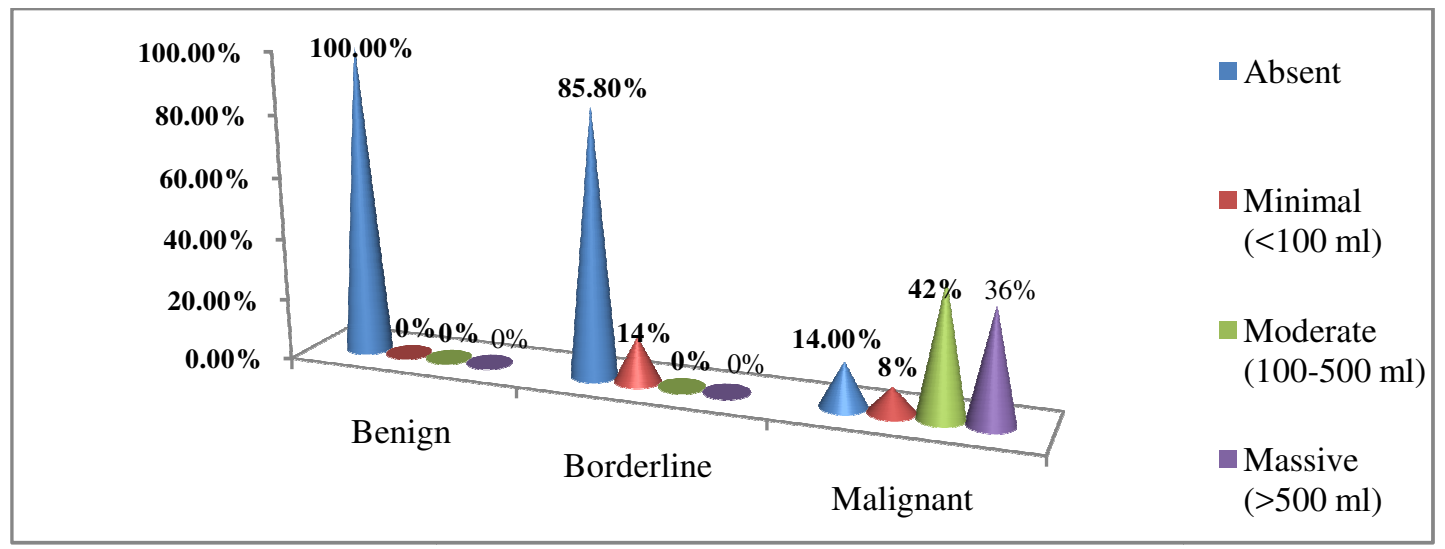

Fig-1: Distribution of ascites among surface epithelial ovarian tumors

majority of surface epithelial ovarian carcinomas were in stage III ( $80 \%)$ followed by stage IV (17.5\%). The borderline epithelial tumors were predominantly stage II $(2.5 \%)$ diseases. This finding was statistically highly significant $(\mathrm{p}=0.0001)$

Thirty nine out of forty cases of malignant ovarian tumors with thrombocytosis were in advanced stage of disease (stage III /stage IV) and $1(2.5 \%)$ case which was in stage II disease. Thirtytwo (80\%) cases were in stage III and $7(17.5 \%)$ cases were in stage IV. This correlation of thrombocytosis in malignant ovarian tumors with advanced FIGO stage was statistically highly significant ( $\mathrm{p}=0.0001)$ (Table 5).

\section{Discussion}

Pre-operative thrombocytosis is associated with many malignancies including ovarian neoplasia. According to recent WHO classification, the ovarian tumors have been classified into benign, borderline and malignant tumors which are further classified into their histologic subtypes. One hundred and sixty cases of surface epithelial ovarian tumors were included in our study. Majority of the study cases were benign (64.43\%) followed by malignant $(31.3 \%)$ and borderline $(4.4 \%)$ tumors. The correlation of thrombocytosis with presence and degree of ascites, and FIGO staging were analyzed among malignant ovarian tumors.

The mean age in the present study was 43.64 years (1780 years) which is lower than those reported by other studies. The mean age for malignant cases was 53.18 years (35-80 years), similar to the study done by Bouanene et al [27]. Age recorded in our study was lower than the studies done by Li et al, Soonthornthum et al, Ziemet et al, Obermair et al and Bozkurt et al(59 years, 62.37 years, 58 years, 59.9 years and 54 years respectively) [7, 9, 21, 28-29]. The results were higher than the studies done by Crasta et al and Chalas et al (51.2 years and 50 years) [5,23]. In the present study, the mean platelet count was $321 \times 10^{9} / \mathrm{L}$ and the platelet count ranged from $172 \times 10^{9} / \mathrm{L}$ to $641 \times 10^{9} / \mathrm{L}$. The mean platelet counts for malignant epithelial ovarian tumors (ovarian carcinoma) was $435 \times 10^{9} / \mathrm{L}\left(226 \times 10^{9}\right.$ $/ \mathrm{L}$ to $\left.641 \mathrm{X} 10^{9} / \mathrm{L}\right)$ similar to the study done by Levin and Conley $\left(>400 \times 10^{9} / \mathrm{L}\right)[4]$. Count in the present study was lower than the studies done by Crasta et al, $\mathrm{Li}$ et al and Bozkurt et al $\left(610 \times 10^{9} / \mathrm{L}, 542 \times 10^{9} / \mathrm{L}\right.$ and $446 \times 10^{9} /$ Lrespectively)[5,7,29]. But the count was higher than the results conducted by Kerpsack and Finan $\left(298 \times 10^{9} / \mathrm{L}\right)[24]$. Forty $(80 \%)$ out of fifty cases of malignant surface epithelial ovarian tumors had preoperative thrombocytosis as compared to only three $(42.9 \%)$ cases of borderline tumors and six $(5.8 \%)$ cases of benign tumors. These findings were statistically significant $(\mathrm{p}=0.0001)$ and higher than other studies done by Levin and Conley, Crasta et al, $\mathrm{Li}$ et al, Soonthornthum et al, Ziemet et al, Menczer et al, Chalas et al, Kerpsack and Finan, Gastl et al and Lund et al $(40 \%, 37.5 \%, 22.4 \%, 35 \%, 38 \%, 62.5 \%, 56 \%$, $54.2 \%, 37.5 \%$ and $22.4 \%$ respectively) [4-5,7,9,2124,30-31].

In the present study, ascites was present in 44 cases (27.5\%), out of 160 cases. Ascites was more prevalent in malignant epithelial ovarian tumors (86\%) as compared to borderline tumors (14\%), which was higher than the studies done by Shen-Gunther and Mannel, and Puiffe et al (42\% and 33\%) [32,33]. Among malignant ovarian tumors with ascites, majority of the cases had moderate (42\%) to massive ascites (36\%) followed by minimal ascites seen only in $8 \%$ cases. All the borderline cases had minimal ascites and it was absent in all the benign ovarian tumors. In our study, statistical significance was associated with the presence or absence of ascites with FIGO staging ( $\mathrm{p}=0.0001)$, which is similar to the results seen in 


\section{Original Research Article}

Bouanene et al $(p=0.020)$ [27]. In this study, majority of the ovarian carcinomas were in advanced stages (stage III- $72 \%$ and stage IV-14\%) followed by $10 \%$ in stage I and $4 \%$ were in stage II disease. This finding was statistically highly significant $(\mathrm{p}=0.0001)$. This finding was similar to the studies conducted by Chalas et al, Ziemet et al, Van der Zee et al, Li et al, Soonthornthum et al, Crasta et al and Lane et al [5,7,9,21,23,34-35].

\section{Conclusion}

Pre-operative secondary thrombocytosis is a frequent finding in malignant epithelial ovarian tumor (ovarian carcinoma) and is significantly associated with the presence and degree of ascites as well as advanced FIGO stage. This implies that pre-operative thrombocytosis is probably a marker of tumor aggressiveness, and that platelet may have a role in cancer growth and progression. Thus, the presence of pre-operative thrombocytosis has significance as a poor prognosticator in ovarian carcinoma.

\section{Contribution from the Author}

Dr. Shwetha Ramu: Data Collection, Analysis and preparation of Manuscript, Dr. Supriya Sandeepa: Analysis and Preparation of the Manuscript. Dr. Ruchi Sinha: Data Collection, Analysis and preparation of Manuscript. Dr. Narayana Murthy: Analysis and Preparation of the Manuscript.

Funding: Nil, Conflict of interest: None initiated Permission from IRB: Yes

\section{References}

1. Mitus AJ, Schafer AI. Thrombocytosis and thrombocythemia. Hematol Oncol Clin North Am 1990 Feb; 4 (1): 157-78.

2. Griesshammer M, Bangerter M, Sauer T, Wennauer R, Bergmann L, Heimpel H. Aetiology and clinical significance of thrombocytosis: analysis of 732 patients with an elevated platelet count. J Intern Med 1999 Mar; 245 (3):295-300.

3. Santhosh-Kumar CR, Yohannan MD, Higgy KE, AlMashha-dani SA. Thrombocytosis in adults: analysis of 777 patients. J Intern Med 1991 June; 229(6):493-5.

4. Levin J, Conley CL. Thrombocytosis associated with malignant disease. Arch Intern Med 1964 Oct;114 (4): 497-500.

5. Crasta JA, Premlatha TS, Krishnan SM, Vallikad E, Rameshkumar K. Significance of preoperative thrombocytosis in epithelial ovarian cancer. Indian $\mathrm{J}$ Pathol Microbiol 2010 Jan 19;53(1):54-6.
6. Gücer F, Tamussino K, Keil F, Balkanli-Kaplan P, Yüce MA. Thrombocytosis in gynecologic malignancies. Anticancer Res 2004;24:2053-60.

7. Li AJ, Madden AC, Cass I, Leuchter RS, Lagasse LD, Karlan BY. The prognostic significance of thrombocytosis in epithelial ovarian carcinoma. Gynecol Oncol 2004 Jan;92(1):211-4.

8. Tranum BL, Haut A. Thrombocytosis: platelet kinetics in neoplasis. J Lab Clin Med 1974 Nov;84 (5): 615-9.

9. Soonthornthum T, Suraseraneewong V, Kengsakol K, Wijaithum K, Kasemsan P, Prommatt S. Thrombocytosis in advanced epithelial ovarian cancer. J Med Assoc Thai 2007;90(8):1495-500.

10. Pedersen LM, Milman N. Diagnostic significance of platelet count and other blood analyses in patients with lung cancer. Oncol Rep 2003 Jan-Feb;10(1):213-6.

11. O'Keefe SC, Marshall FF, Issa MM, Harmon MP, Petros JA. Thrombocytosis is associated with a significant increase in the cancer specific death rate after radical nephrectomy. J Urol 2002 Oct;168(4 pt 1): 1378-80.

12. Ikeda M, Furukawa H, Imamura H, Shimizu J, Ishida $\mathrm{H}$, Masutani $\mathrm{S}$, et al. Poor prognosis associated with thrombocytosis in patients with gastric cancer. Ann Surg Oncol 2002; 9: 287-91.

13. Benoy I, Salgado R, Colpaert C, Weytjens R, Vermeulen PB, Dirix LY. Serum interleukin 6, plasma VEGF, serum VEGF and VEGF platelet load in breast cancer patients. Clin Breast Cancer 2002Jan;2(4):311-5.

14. Schwarz RE, Keny H. Preoperative platelet count predicts survival after resection of periampullary adenocarcinoma. Hepatogastroenterology 2001 Set-Oct; 48 (41): 1493-8.

15. Costantini V, Zacharski LR, Moritz TE, Edwards RL. The platelet count in carcinoma of the lung and colon. Thromb Haemost 1990; 64:501-5.

16. Tamussino KF, Gucer F, Reich O, Moser F, Petru E, Scholz HS. Pretreatment haemoglobin, platelet count, and prognosis in endometrial carcinoma. Int $\mathbf{J}$ Gynecol Cancer 2001 Dec 20;11:236-40.

17. Scholz HS, Petru E, Gucer F, Haas J, Tamussino K, Winter R. Preoperative thrombocytosis is an independent prognostic factor in stage III and IV endometrial cancer. Anticancer Res 2000 Sep 1;20(5C): 3983-5. 


\section{Original Research Article}

18. Gücer F, Moser F, Tamussino K, Reich O, Haas J, Arikan G, et al. Thrombocytosis as a prognostic factor in endometrial carcinoma.GynecolOncol1998;70:210-4.

19. Hefler L, Mayerhofer K, Leibman B, Obermair A, Reinthaller A, Kainz C, et al. Tumoranemia and thrombocytosis in patients with vulvar cancer. Tumour Biol2000;21:309-14.

20. Lavie O, Comerci G, Daras V, Bolger BS, Lopes A, Monaghan JM. Thrombocytosis in women with vulvar carcinoma. GynecolOncol 1999 Jan;72(1):82-6.

21. Zeimet AG, Marth $\mathrm{C}$, Müller-Holzner $\mathrm{E}$, Daxenbichler G, Dapunt O. Significance of thrombocytosis in patients with epithelial ovarian cancer. Am J Obstet Gynecol 1994 Feb;170(2):549-54.

22. Menczer J, Schejter E, Geva D, Ginath S, Zakut H. Ovarian carcinoma associated thrombocytosis. Correlation with prognostic factors and with survival. Eur J GynaecolOncol 1998;19(1):82-4.

23. Chalas E, Welshinger M, Engellener W, Chumas J, Barbieri R, Mann WJ. The clinical significance of thrombocytosis in women presenting with a pelvic mass. Am J Obstet Gynecol 1992; 166:974-7.

24. Kerpsack JT, Finan MA. Thrombocytosis as a predictor of malignancy in women with a pelvic mass. $\mathbf{J}$ Reprod Med 2000 Nov 1;45(11):929-32.

25.Gupta G P, Massagué J. Platelets and metastasis revisited: a novel fatty link. J Clin Invest 2004 Dec 15; 114 (12):1691-3.

26. Tavassoli FA, Devilee P. Pathology and genetics of tumors of the breast and female genital organs. Lyon: International Agency for Research on Cancer; 2008. P.114.

27. Bouanene H, Harrabi I, Ferchichi S, Limem HB, Miled A. Factors predictive of elevated serum CA125 levels in patients with epithelial ovarian cancer. Bull Cancer 2007;94:E18-22.
28. Obermair A, Handisurya A, Kaider A, Sevelda P, Kölbl H, Gitsch G. The relationship of pretreatment serum haemoglobin level to the survival of epithelial ovarian carcinoma patients. Cancer 1998 Aug 15;83: 726-31

29. Bozkurt N, Yuce K, Basaran M, Kose F, Ayhan A. Correlation of platelet count with second-look laparatomy results and disease progression in patients with advanced epithelial ovarian cancer. Obstet Gynecol 2004 Jan;103(1):82-5.

30. Gastl G, Plante M, Finstad CL, Wong GY, Federici MG, Bander NH, et al. High IL-6 levels in ascitic fluid correlate with reactive thrombocytosis in patients with epithelial ovarian cancer. Br J Haematol 1993 Mar; 83 (3): 433-41.

31. Lund B, Williamson P. Prognostic factors for outcome of and survival after second-look laparotomy in patients with advanced ovarian cancer. Obstet Gynecol 1990 Oct 1;76(4):617-22.

32. Shen-Gunther J, Mannel RS: Ascites as a predictor of ovarian malignancy. Gynecol Oncol 2002 Oct; 87 (1): 77-83.

33. Puiffe ML, Le Page C, Filali-Mouhim A, Zietarska $\mathrm{M}$, Ouellet V, Tonin PN, et al. Characterization of ovarian cancer ascites on cell invasion, proliferation, spheroid formation, and gene expression in an in vitro model of epithelial ovarian cancer. Neoplasia 2007 Oct; 9 (10):820-9.

34. van der Zee AGJ, de Cuyper EMJ, Limburg PC, de Bruijn HWA, Hollema H, Bijzet J, et al. Higher levels of interleukin-6 in cystic fluids from patients with malignant versus benign ovarian tumors correlate with decreased haemoglobin levels and increased platelet counts. Cancer 1995;75:1004-9.

35. Lane D, Matte I, Rancourt C, Piche A. Prognostic significance of IL-6 and IL-8 ascites levels in ovarian cancer patients. BMC Cancer 2011 May 30;11:210-15.

\section{How to cite this article?}

Ramu S, Sandeepa S, Sinha R, Murthy N. Secondary Thrombocytosis as a poor prognostic indicator in ovarian carcinoma. Trop J Path Micro 2018;4(3):281-287.doi:10. 17511/jopm.2018.i3.08 